\title{
Introduction: Nation, Film, Child
}

\author{
Stephanie Hemelryk Donald, Emma Wilson and Sarah Wright
}

The proposition underlying this book is not only that each of its three organizing concepts - the child, the nation and cinema - can sometimes illuminate unexpected aspects of the other two, but above all that the three taken in conjuncture offer unique insights into the ways in which people experience and negotiate a sense of place, a sense of history and a sense of self in the contemporary, changing and uncertain world.

Bringing together 'nation' and 'cinema' in the idea of 'national cinema', understood as a body of films that are supposed to speak for as well as to a nation - in effect giving an identity and a unifying story to 'the nation' and so helping to bring the imagined ethnonationalist collectivity into being - has long been a staple of film studies. ${ }^{1}$ In the decades since 1980, the specifically national rubric has been subject to extensive criticism and reconceptualization, as greater emphasis has been placed on 'transnational' and 'world' cinema. ${ }^{2}$ Our return to the question of the nation here is informed by that thinking, which provides the context in which the contributions consider how, within a complex environment of meaning, attraction, identification and spectatorship, 'the nation' continues to provoke narratives and narrational practices that warrant examination. The authors ask how the nation is articulated in film and why the question of the nation (or what is sometimes called 'the state of the nation') has been important to film-makers over the past thirty or forty years - a period during which the persistence or resurgence of national sentiment as a paradoxical by-product of economic globalization has been a topic of much public debate and political anxiety. It is tempting to state the obvious, and to say that film is such a powerful vehicle of description and poetry that it is not in the least surprising if film-makers use their craft to comment on geo-political forces that shape contemporary lives, or that they should do so through the extraordinary mixture of realism, fantasy and emotional appeal that film alone allows.

Introducing the third term of 'the child' both unsettles and catalyses the bipartite relationship between 'nation' and 'cinema'. Whatever the state of 
childhood for actual children, the idea of the child is without doubt a potent symbol for the nation state, for the ethno-national group, and for those who wish either to defend or to abjure national histories and collective memories alike. This book, then, is not a study of national cinemas. Rather, the contributors, who represent a range of national standpoints and perspectives, offer a critical examination of just some of the many films from around the world that have, in recent decades, deployed the figure of the child as a national avatar, or as a metonym for national affiliation, intra-national encounter or communal dissolution. The complex relations between national borders, languages and political cultures inevitably produce conflicted representations of the national subject, all of which require politically informed and culturally nuanced readings of film texts. 'World cinema' is here understood less as a commercial label than as a discursive site for the mapping and remapping of local, national and transnational understandings of both child and nation. It provides a space within which to explore themes of belonging, encounter and experience, as well as agency and representation, while the category of childhood is itself in slippage across classes, ethnicities and regions. In this context, the child can act as a pivot between national, local concerns and wider, transnational identifications. Either the child on film provokes claims on the nation or the nation claims the child.

Childhood has a peculiar subjective status in most modern societies. Although it is generally acknowledged that a child has rights to certain benefits (health, education, housing, and security), the rights of the child to her/his own symbolic value remain vexed. (This is evident from debates in the United States about childhood innocence, futurity and the protection of children.) ${ }^{3}$ The figure of the child thus oscillates between agency and allegory. Explorations of a child's agency on screen can push at the boundaries of film theory to create a 'new cinematic politics of childhood' in cinematic portrayals of the child's experience. ${ }^{4}$ Allegorically, the child can feel pressure from the past (even when that past is imaginary), and yet be called upon to also represent hopes for the future. This makes the child a powerful symbol for nations coming to terms with shifting political or social changes, both as a mode of representation to themselves and as a projection to the wider world.

The book focuses on films produced in the period from 1980 to the present. During this time, political and academic debates about the national, the transnational and the global have been reflected in world cinema. Our contributors address films in a variety of national contexts, but they are alert to issues of border crossing, and cross-border encounter, including territories 
where the idea of the nation came under acute pressure internally and externally in the latter twentieth century. Borders are not necessarily as marked on a map, but nor are invisible or excised borders quickly forgotten.

Nation, film, child: the three words that hold the book together indicate ideas and practices on which the modern subject relies for a perspective on place and experience, and for a sense of grounded historicity. Belonging, background, representation and fantasy combine in films that exploit both nation and childhood in their address to the adult spectator.

Vicky Lebeau has said of film that it works 'as if the human mind can lose itself in a technology that comes too close to it, a technology that repeats the mind, as it were. ${ }^{5}$ That is the nub of why film remains potent and particular to national audiences, both as propaganda and as resistance, both as an appeal to belonging and as a reason to step away. The proximity of implied collective identity encroaches on the boundary between an individual spectatorial position and a human mind that understands its social and political context through place. The same might be said of the child. Looking at a child and thinking about childhood, at least in the abstracted context of visual representation, the human mind loses an element of distance, or at least its span of judgement shifts. Emotional impact and identification are (arguably, of course) sharper on screen when there is a child protagonist in play, whether because we take responsibility for the child or because we project our own remembered childishness onto the protagonist. An intensity of recognition occurs, albeit one that is highly mobile depending on the performance and our capacity to relate to a context-specific form of child behaviour. For instance, when watching The Innocents (1961), Jack Clayton's adaptation of Henry James's The Turn of the Screw, the uncanny quality of the film derives in large part from the instability of the children's childishness, and this uncertainty occupies the centre of the story. Are they children at all, or are they, as the governess comes to suspect, possessed by adults playing out adult desires? If they are simply naughty children, then how should we judge the increasingly bizarre behaviour of their governess? When the extraordinary Flora (Pamela Franklin) and Miles (Martin Stephens) whisper to each other on their way into church, are they devilish? Or, are they idiosyncratic versions of the hilarious little girls in the British Channel 4 documentary The Secret Life of 4 Year Olds $(2015)^{6}$ where one whispers fervently to the other, 'You know that bully boy, if he troubles you, just bite him'? Although these are entirely different pieces of filmmaking, neither of which is particularly interested in national identification (although that occurs nonetheless), the two examples are instructive for what 
they can tell us about adult investments in cinematic portrayals of the child with their staggered point of view. ${ }^{7}$ Our point, however, is that the child on film is the essence of what cannot be normally seen, that drifts to the uncanny, hovering disquietingly between what adults need or desire and what they fear.

The notion of the child as an invisible yet potent protagonist in human existence underpins the provocative address of the cinematic child. It is, for example, a reasonable assumption that most adults are shocked when they see images of children hurt in war. 'Q. And babies? A. And babies.' The famous antiVietnam War campaign poster featured children running from a napalm fire in South Vietnam. One girl was naked, her youth shockingly exposed as both victim-image and human agent running for her life towards us and away from attacks that 'we', the assumed American public in this instance, had caused. As the use of the photograph with such a caption emphasizes 'A. And babies', it is supremely shocking and wicked to hurt someone so young and so vulnerable in the pursuit of war, here the 'hot' Cold War as it was waged in Vietnam. ${ }^{8}$

Yet, as the photographer knew and we surely know, children are all too frequently hurt by war, by national upheavals, by any set of circumstances that undermines adult capacity to care for their families and the population as a whole. Why might we be moved or surprised by the obvious and likely impact of our political decisions or apathy? Nonetheless, when the child is pulled to the foreground onscreen, their suffering is marshalled to make us register surprise and shock, and to justify a larger national narrative of victimhood and recrimination. When what is at stake is a disputed narrative - and we think here, in this book, of Stephanie Hemelryk Donald and Klāra Brūveris on 1990s and 2000s films on the Latvian deportations in the 1940s or Victoria Flanagan on differing perspectives on education and national belonging in contemporary France - the child's body challenges arguments or biases represented by the adults through the sheer clarity of their unexpected and yet inevitable presence.

The harmonious and disharmonious classrooms of France are small dramas with hints of potentially massive results as children become adults and history enters the present. A disenfranchised child who may be legally French but is ashamed of that status shares a conundrum with children who have been forcibly separated from their identities over the past century of global turmoil. They have in common a confusing and destructive relationship with whatever formations of national belonging apply. Whether in the multiple genocidal tragedies of the European theatre of war of the 1940s, in Chilean and Argentinian attacks on dissident populations, or in Australian and Russian ethnic cleansing practices of 
the twentieth century, the damaged or lost child appears as it were from behind the skirt of their missing protectors to confront and refute the very idea of a safe modern world where we watch film with impunity.

The contributors to this book are interested in films in which some profound national drama is at stake, or in which child protagonists reveal aspects of national life that are either unsettling or unacknowledged in other films. Their discussions necessarily touch on the notion of trauma, but this is not a treatise about trauma on screen. The figure of the child may often embody the idea of the nation under stress, but this situation is not always played out in obviously traumatic scenarios. Rather, the child's daily experience is likely to describe the nation's psychical, economic and political failings to itself in ways that a national culture might otherwise ignore. Film-makers do not all share the same impulses or practices. Some films have strong allegiance to specific narratives of the nation, while others seek to question national coherence through the minutiae and clarity of a child's eye view.

Vicky Lebeau's chapter on Ratcatcher addresses a global question about a child's right to secure housing, but she does so through the very local story of a disadvantaged Scottish boy whose life chances are severely impeded by the failure of society to create liveable homes for the poor. Her discussion ranges across reports from the House of Commons in the immediate post-war period to a critique of contemporary housing policies and legislation that attacks the poor. In late 2015, the British Government was accused of undermining the educational capacity of poor children in social housing through the bedroom tax. In one example, cited in the social science literature, one finds a sixteenyear-old sharing a room with a two-year-old in order to avoid paying the newly increased rent for a third bedroom in a family home. ${ }^{9}$ Lebeau's chapter integrates this kind of discussion with a powerful analysis of a film that she recognizes as possessing the 'art of listening' to children and circumstances that have been troped in the British social realist documentary but whose stories are now increasingly visible in fiction film. On the other side of the world, Ivan Sen's film Toomelah and Catriona MacKenzie's Satellite Boy do similar work for Indigenous Australian boys. In Toomelah we meet Daniel, a ten-year-old whose housing is also poor and whose prospects are dismal in any upwardly mobile sense of the term. All these are films might have been conceived as social documentaries, but have succeeded as fiction and semi-fiction, both thinking with and on behalf of the child protagonists at their centres. Greg Dolgopolov argues that there is a new wave of Indigenous films where the child achieves a rite of passage in 
a contemporary version of the Australian bush. These latter-day walkabouts rebuke the paranoid 'lost white child' anxiety of earlier Australian cinema while finding a place for non-normative child life choices and child risk-taking on screen. The lost child trope is not new to those familiar with Australian arts and film, but Dolgopolov argues that films which reclaim categories both of being lost but also of knowing the way afford symbolic vitality to the Indigenous child's claim on the national imagination and to the voices of Indigenous film-makers in a challenging landscape. Dolgopolov suggests that onscreen Indigenous children have claimed cinematic space in ways that refuse to comply with invisibility or acquiescence. The historical undercurrent to his chapter is the history of Indigenous child removals in the interests of a hegemonic white colonial state. These films tell local stories, but their attention to the visibility of Indigenous childhoods is crucial for the cinematic recuperation of the children and grandchildren of the Stolen Generations. ${ }^{10}$

The book starts, then, with two chapters premised on historical knowledge necessary to the reading of the cinematic child in a national conversation. This approach is common to many chapters that follow, albeit in varying degrees. We identify matrices of sociality, risk, and intimacy (Home and Away), of the push and pull of agency in historical narrative (Disappearance and Removal), of institutional confinement and space to play (Education and Serious Games), and of capitalist expectations and child labour, including that of the actor her/ himself (Performance). Intertextual encounters between these sections should, we hope, allow the reader to make further comparative observations.

We also have collected contributions with a commitment to an interdisciplinary approach. Lebeau works through psychoanalysis to understand film. Dolgopolov works on festival culture in Indigenous Australia - and is most concerned with the narratives derived by Indigenous audiences from films made by Indigenous artists. Jan Láníček is an historian. For him film is a document, in which the filmmaker and their audience narrate history, but in so doing betray the narrational lacunae of their own period. He is interested here in how wartime history is remade in Czech film and the extent to which this betrays the historical memory of other sub-national groups, specifically Czech Jews. Láníček focuses on screen dramas that attempt an account of 1940s child removal by German agencies for social engineering, eugenic and genocidal purposes. In these films, the very DNA of the Czech national body is at stake. Stephanie Hemelryk Donald and Klāra Brūveris also investigate instances of disappearance, deportation, separation and murder in wartime Europe, where the story of childhood is synonymous 
with narratives of national mourning and shame. They engage with a film-maker who reiterates Latvian wartime sufferings through annual television films with a primary emphasis on child disappearance. This is the scaffolding for a version of national identity premised on remembered attacks on the national body. That body is a collective organism, the lost Latvian children becoming a proxy for a lost national childhood, and from that is extrapolated a lost nation. The paradox is that this story of loss nevertheless underpins Latvian identity even today paradigmatically through these films. Here again, the figure of the child is deliberately invested with a national DNA to the exclusion of any other ethnic legitimacy.

The temporal and spatial scaling of the suffering of children to fit national pathologies continues in an essay on South Korea. Susan Danta's art practice as an animator draws on her family's history of escape from North to South Korea. As she argues here, the South has its own negative pathology that affects children quite directly. The high suicide rate among school-age children is attributed to what is termed as the national characteristic of mourning (han), but Danta explains how fellow animator Sang-Ho Yeon's nightmarish vision of bullying in a school playground amounts to a refusal to accept the concept of immutable national characteristics. Yeon offers instead an exposé of historical contingency and response.

Jordana Blejmar describes the use of toys, specifically Barbie and associated dolls, in subversive films from Argentina. Once more, we find cinema concerned with the animation of national pathologies. Stories of disappearance, exclusion and loss - of children and of adults - are explored in apparently child-friendly aesthetic forms. Blejmar argues that the use of dolls expresses the central significance of childhood pain in national self-narrativization. It is not the actual filmed body of the child that takes on the representative weight of a nation's shame, guilt or anger, but the child is there nonetheless. She is embodied through the toy-object created by an adult economy of consumer desire and, here, a cinematic surrogate for the child's body and the child's vulnerability to a state's violent corruption.

Jennifer Beckett's discussion of friendship on the streets of Belfast during the Troubles, produces a compelling vision of the child's metonymic relation to a disturbed and violent environment. Micky Bo and Me (2005) is a coming-of-age story told through voiceover of the main protagonist. The film describes the loss of childish freedom in exchange for integration and safe alliance with the group. As Beckett notes, a coming-of-age film is generally organized around a 
summer of late adolescence, or a significant traumatic event, but here, in the context of continuing upheaval, it is organized through the longer timeframe of the Troubles (the period of civil strife in Northern Ireland that lasted from 1968 until 1998). Beckett's observation allows us to suggest that many of the films and arguments contained in this book are similarly concerned with the temporal relationship between child and film, nation and child, agency and compliance. Questions such as who narrates the film, who acts in it, whose photographs are deployed and with what background, and whose survival counts in the end, are afforded by the time and space which informs each film under discussion. The spatialized marginality of the child is bound then by specific formations of time. Some of these formations indicate proximity to, or even a perverse surrogacy of, the national myth of origin and bloodline; others indicate resistance or exclusion.

Questions about children's agency articulated from the margins emerge in the chapters by Sarah Wright and by Emma Wilson. Wright considers how her Chilean child protagonists refashion everyday materials to recreate a makeshift spool of film, which offers a site of resistance to the political landscape of disappearance and uncertainty which surrounds them while at the same time situating this little-known pedagogical film within a wider politics of film history and film theory. Wilson, meanwhile looks at a fairy tale adaptation, Catherine Breillat's Bluebeard which, while moving from national history to fantasy, explores a young girl's departure from her child self in a bid to achieve agency and subjectivity. This feminist retelling opens up questions about a young girl's choices and her desires within patriarchy, confronting and redrawing images of childhood vulnerability. Hannah Kilduff's subtle reading of Yamina Benguigui's Inch'allah Dimanche, a film also made in the context of the French film industry, but telling the story of an Algerian immigrant family reunited in France, is multivalent in its exploration of child agency embodied here in the foregrounded work of the child actors. Benguigui's work with these children, and the hesitations and lack of artifice in their onscreen presence, are seen to open to a real experience, while within the diegesis the children are also used to think through an immigrant future and integration in France. As Kilduff writes, with words that resonate with so many chapters in the book: 'The figure of the child negotiates between the universal and the specific, the historical and the personal and the past and the present.' Michael Lawrence explores the relationship between the national and the transnational in a Bollywood remake of an Iranian film, observing the changes made in the process in order to trace how far we can speak of the child's universality, and how far the child is 'embedded within the material particularities 
of time and place. At the same time, Lawrence expands on the question of child labour as a situated opportunity that cannot but reveal the indices of privilege. His example - of a film that crosses from Iran to Bollywood - sidesteps the easy distinction between the West and the Other, a comparison that has outlived its usefulness in an era of second and third generation post-war migration when the identity and belonging of national bodies is again contested. That is underlined by the chapter on left-behind children in China by Zitong Qiu and Maria Elena Indelicato. 'Left-behind' refers to rural children whose parents are domestic migrants to major cities looking for work. The treatment of such children on film is quite rare, but a film that has been made is discussed here in the context of a national performative aesthetic of melodrama. The legibility of that aesthetic depends on qualities of mourning and sentimentality that are very familiar to the Chinese filmgoer. The melodramatic mode might also open up questions of the role of rural suffering in the larger and longer engagement of city and countryside in Chinese literature and arts.

If the Algerian-French children in Kilduff's chapter redraw forms of belonging in contemporary France and Qiu and Indelicato's left-behind children show who may only belong through a specific aesthetic, Stefan Solomon turns his attention to Raúl Ruiz's articulation of childhood as moving fluidly between an adopted home, Portugal, and the traces of a homeland, Chile, returned to after a period of exile. The cinema of childhood becomes a way to resist the paralysing effects of a conservative education. Blejmar, already discussed for her contribution to notions of resistance and surrogacy, recasts the notion of child presence on screen through a discussion of synthetic performance in Argentinian narratives of dissent.

Childhood happens at home, in playgrounds, in classrooms or in the fantasy worlds of a child's ambition. Their micro-borders borders of imagination and experience intersect with the great narratives of political borders and conflict. Film-makers engage with childhood so that these encounters are actualized, seen and known. Fantasy and desire are thus tied into the worlds of children through the imaginaries that they enable, even as they compete with the intersecting and demanding worlds of adults and their national sensibilities and psychoses. Across all the geographically and stylistically diverse films discussed in this book, and through the range of particular experiences they imagine and re-present, we hope to draw attention to the specificity and diversity of individual children's lives, to vulnerability and to resilience, within and between nations, at home, at the border, in transition, in new encounters. 


\section{Notes}

1 See, for example, Andrew Higson, 'The Concept of National Cinema', in Film Studies: The Essential Resource, ed. Peter Wall, Andrew Hickman and Peter Bennett (London: Routledge, 2006). (First published in Screen 30, no. 4 [1989]).

2 See, for example, Sheldon Lu, 'Historical Introduction: Chinese Cinemas (1896-1996) and Transnational Film Studies', in Transnational Chinese Cinemas: Identity, Nationhood, Gender, ed. Sheldon Lu (Hawaii: University of Hawaii Press, 1997), 1-31, http://www.uhpress.hawaii.edu/books/lu-transintro.pdf (accessed 25 January 2016); Lúcia Nagib, 'Towards a Positive Definition of World Cinema', in Remapping World Cinema: Identity, Culture and Politics in Film, ed. Stephanie Dennison and Song Hwee Lim (London: Wallflower Press, 2006), 30-7; Lúcia Nagib, World Cinema and the Ethics of Realism (London: Continuum, 2011); Mette Hjort and Scott MacKenzie, Cinema and Nation (London: Routledge, 2000); Mette Hjort, Small Nation, Global Cinema (Minneapolis: University of Minnesota Press, Public Worlds Series, 2005).

3 Henry Jenkins, The Children's Culture Reader (New York: NYU Press, 1998); Lee Edelman, No Future: Queer Theory and the Death Drive (Durham: Duke University Press, 2004).

4 Emma Wilson, 'Children, Emotion and Viewing in Contemporary European Cinema', Screen 46, no. 3 (2005): 332.

5 Vicky Lebeau, Childhood and Cinema (London: Reaktion, 2008), 47.

6 Channel 4 is a British television and film producer and broadcaster.

7 David Martin-Jones, Deleuze and World Cinemas (Continuum: London, 2011).

8 The poster depicts a horrifying image of dead children in rural Vietnam after an American airstrike. Artists Poster Committee (Frazier Dougherty, Jon Hendricks, Irving Petlin), Q: And Babies? 1970: Center for the Study of Political Graphics, Los Angeles. Photo: Ron L. Haeberle.

9 The editors found an example with worrying ease:

By the rules, my daughter is not 16 years old, and she can share one room with the little one [aged 2]. Again, it is not possible, because the little one is shouting in the night, crying in the day, and there is a big gap between them, an ages gap. ... They cannot share one room. It is not possible for them, because my daughter studies very hard, and the little one is a baby. They live by themselves in rooms now, but I have to pay because by law, I have a spare room. (\#24, Female, 36)

Quoted in S. Moffat et al., 'A Qualitative Study of the Impact of the UK "Bedroom Tax"', Journal of Public Health (Advance Access 15 March 2015): 1-9, 6. 
10 'Stolen Generations' refers to Indigenous children removed from their families between 1905 and 1969 for training in institutions. The tragic impact of removal, abuse and subsequent exclusion from their communities has become a major theme in recent Australian film and literature. See the Bringing Them Home report (1997), available online at https://www.humanrights.gov.au/publications/bringingthem-home-report-1997 (accessed January 2016). 
